\title{
CO-APPLICATION OF HUMIC ACID AND BACILLUS STRAINS ENHANCES SEED AND OIL YIELDS BY MEDIATING NUTRIENT ACQUISITION OF SAFFLOWER (CARTHAMUS TINCTORIUS L.) PLANTS IN A SEMI-ARID REGION
}

\author{
EKIN, Z. \\ Faculty of Agriculture, Department of Field Crops, Van Yuzuncu Yil University, Van, Turkey \\ (e-mail:zehraekin@yyu.edu.tr; phone: +90-432-225-1056; fax: +90-432-225-1104) \\ (Received $16^{\text {th }}$ Nov 2019; accepted $30^{\text {th }}$ Jan 2020)
}

\begin{abstract}
Faced with the deterioration of natural resources, current trends in agriculture are focused on seeking eco-friendly methods to improve plant growth promotion and crop productivity. Plant growth promoting rhizobacteria (PGPR) and humic substances can improve crop production in sustainable farming due to their various features. This study examined how humic acid (HA) and inoculation with PGPR (Bacillus megatorium and Bacillus subtilis) affect the agronomic performance of safflower (Carthamus tinctorius L.) in a semi-arid environment. In the field experiments, PGPR inoculated and non-inoculated safflower seeds were cultivated in soil treated with humic acid $(0,200,300$, and $400 \mathrm{~kg}$ $\left.\mathrm{ha}^{-1}\right)$, alone or in combination. It was observed that PGPR and HA improved growth, yield parameters and seed mineral contents. Their plant growth responded positively to inoculation with Bacillus sp. strains owing to the $\mathrm{N}$-fixing and $\mathrm{P}$-solubilizing capabilities, whereas greatly positive response in the seed yield and quality was found when applied in combination with humic acids. The combined application of 300 and $400 \mathrm{~kg} \mathrm{ha}^{-1} \mathrm{HA}$ with Bacillus subtilis inoculation enhanced seed and oil yields by an average of $162 \%$ and $221 \%$ relative to the control plants. This study confirms that integrated management strategies can ensure higher crop productivity of safflower in sustainable and semi-arid environments.

Keywords: energy crop, humic substances, plant growth promoting rhizobacteria, seed yield, sustainable agriculture
\end{abstract}

\section{Introduction}

Safflower (Carthamus tinctorius L.) is an annual oilseed and energy crop belonging to the Asteraceae family. The crop was once grown for colorful petals used in food coloring, fabric dyes, flavoring agent and medicinal use (Ekin, 2005). Nowadays, scientific interest in this species is mainly due to its high quality vegetable oil for nutritional and industrial applications. However, safflower has gained importance in recent years as a result of its vegetable oil for human consumption and biodiesel production in arid and semi-arid regions in the world. Safflower is also one of the most adapted oilseed crops to dryland cropping systems with good drought tolerance due to its deep taproot, but it's sensitive to dry soil condition in which kernel filling (flowering) are affected by water stress conditions (Dajue and Mündel, 2006).

To improve the plant productivity, it is of paramount importance to supply adequate water and nutrient acquisition in semi-arid regions typically characterized by variable and unpredictable rainfall, large diurnal ranges in temperature, frequent strong winds and poor moisture storing capacity of soils (Chavoushi et al., 2019). Moreover, this is crucial to producers in semi-arid regions of world and Turkey, including eastern Anatolia, south eastern Anatolia and central Anatolia. In particular, water resources need to be used efficiently because of the anticipated water scarcity in the face of global warming and the increasing competition between domestic, industrial, and agricultural water consumptions. Therefore, it is imperative to improve the drought tolerance of 
crops as well as its salt tolerance, heavy metal stress tolerance and disease resistance, and to protect soil health and fertility under the changing circumstances. Currently, there are no economically viable technological means to facilitate crop production under various stress conditions. Towards a sustainable agricultural vision, the uses of plant growth promoting rhizobacteria and humic acid might also be a promising alternative eco-friendly approach, which helps in protecting the soil health, increasing the nutrient uptake capacity and water use efficiency and decreasing the effects of drought, salinity and heavy metal pollution etc.

Plant growth promoting rhizobacteria (PGPR) are bacteria colonizing rhizospheres of plant that, unlike fertilizers and pesticides, depend on various mechanisms like nitrogen fixation, solubilization of phosphate, production of different phytohormones like indole-3-acetic acid, gibberellic acid and cytokines for its success in promoting crop yield (Calvo et al., 2014). In this sense, plant growth promoting rhizobacteria can be used to enhance plant health and promote plant growth rate without environmental contamination. For decades, varieties of PGPR including the species Pseudomonas, Bacillus, Enterobacter, Klebsiella, Azotobacter, Variovorax Azosprillum, and Serratia have been well studied in various field crops as rhizosphere-colonizing microorganisms (Glick, 2012), such as wheat (Rosas et al., 2009; Hungria et al., 2010; Rana et al., 2012), sugar beet and barley (Cakmakci et al., 2001, 2006), sugarcane (Silva et al., 2017), sunflower (Shadid et al., 2012), rice (Lucas et al., 2009), bean (Hoyos-Carvajal et al., 2009), canola (El-Howeity and Asfour, 2012), maize (Thonar et al., 2017) and soybean (Cassán et al., 2009). However, only limited data are reported in the beneficial effects of PGPR on safflower growth promotion. The literature on PGPR regarding safflower included mostly Pseudomonas, Azosprillum and Azotobacter spp. inoculation which were used to improve nitrogen uptake (Mirzakhani et al., 2009; Soleymanifard and Sidat, 2011; Sharifi et al., 2017; Nosheen et al., 2018), root morphology (Nosheen et al., 2011) and protein quantity and quality of safflower seeds (Nosheen et al., 2016). The various studies also reported that inoculation of specific PGPR species like $\mathrm{N}_{2}$ fixing Bacillus subtilis and phosphorus solubilizing Bacillus megatorium instead of synthetic chemicals may serve as an effective alternative and environmental friendly practice since they improve plant nutrition by increasing $\mathrm{N}$ and $\mathrm{P}$ uptake by plants (Cakmakci et al., 2001; Esitken et al., 2003). But, up till now no data are available with respect to the use of this genus in safflower plants.

Similarly, humic acid (HA) are naturally-available substance in the soil that are end products of microbial decomposition and chemical degradation of dead biota. Humic substances can promote plant growth through improvement in root architecture and morphology, enhancement of nutrient availability, uptake and translocation, promotion of plant physiology and development due to their hormone-like activities and promotion of soil biological activity (Puglisi et al., 2013; Canellas and Olivares, 2014; Ahmad et al., 2016). In the various experiments, direct effects of humic acid on plant growth were well described in cultivation of various crops, such as potato (Suh et al., 2014), tomato (Olivares et al., 2015), maize (Canellas et al., 2013), Hungarian vetch (Esringu et al., 2016) and blueberry (Schoebitz et al., 2016). However, basic mechanisms and benefits of the combined application of humic substances and plant growth promoting rhizobacteria have been recently demonstrated for several plant species grown under field conditions and have been attributed to an increase in the adaptation of seedlings to stress conditions, which result to cause an increase in the macro- and micro nutrient uptakes and root growth (Nardi et al., 2009; Dobbss et al., 2010; Busato et al., 2012; 
Puglisi et al., 2013; Canellas and Olivares, 2014). Olivares et al. (2015) observed that co-application of humates isolated from vermicompost with diazotrophic endophytic Herbaspirillum seropedicae inoculation can increase significantly nitrate uptake, nitrate reductase activity, fruit biomass, leading to to increased tomato yield. The researchs previously reported that humic substances have potential as enhancer of plant growth promoting bacteria inoculation benefits (Canellas et al., 2013; Esringu et al., 2016; Schoebitz et al., 2016; Silva et al., 2017).

Keeping in view the characteristics of plant growth promoting rhizobacteria and humic acid as a helping way for crop plants to be grown in arid and semi-arid areas we hypothesized that they can enhance the agronomic performance of safflower through the activation of natural processes like nutrient release and uptake by various mechanisms described above. Extensive root system created by improved root growth and architecture by plant growth promoting rhizobacteria and humic acid can also enhance the seed quality by increasing the uptake of nutrients by exploring more and more soil volume. Stimulation of biological activity by humic acid can further enhance nutrient cycling through the action of microorganisms. In this regard, to evaluate the potential of plant growth promoting rhizobacteria and humic acid for agronomic performance of safflower we planned 2 years field experiment in a semi-arid environment. In this experiments we used Bacillus megatorium M3 (P-solubilizing), Bacillus subtilis OSU142 ( $\mathrm{N}_{2}$-fixing) and humic acid (obtained from leonardite).

\section{Materials and Methods}

\section{Study Site}

Field experiments were carried out under rainfed conditions at a research farm located in Ahlat district $\left(38^{\circ} 46^{\prime} \mathrm{N}\right.$ and $42^{\circ} 30^{\prime} \mathrm{E}$ with an altitude of $1722 \mathrm{~m}$ ) in Eastern Anatolia region, Turkey during 2010 and 2011 (Fig. 1). The climate at this location is classified as continental with a total long-term average (1958-2017) precipitation of $562.6 \mathrm{~mm}$ mainly in winter. Annual mean air temperature is $9.3^{\circ} \mathrm{C}$, with an average temperature of $-2.5^{\circ} \mathrm{C}$ in January and $21.9^{\circ} \mathrm{C}$ in July. Annual mean relative humidity is $63.8 \%$. The study site climate variables were collected from weather station and averaged for each month (Table 1). In 2010 and 2011, total precipitation during the crop season (from April to August) was $291.0 \mathrm{~mm}$, and $269.4 \mathrm{~mm}$, respectively, and the long-term average for the same period was $136.2 \mathrm{~mm}$ (Table 1). The mean air temperature was $16.5^{\circ} \mathrm{C}, 16.0^{\circ} \mathrm{C}$ in 2010, 2011, respectively, and long-term average was $16.1^{\circ} \mathrm{C}$.

Table 1. Climate data: Monthly means of climate variables for the crop seasons of 2010, 2011 and long-term average (LTA: 1958-2017) in Ahlat, Turkey

\begin{tabular}{c|ccc|ccc|ccc}
\hline \multirow{2}{*}{ Months } & \multicolumn{3}{|c|}{ Temperature $\left({ }^{\circ} \mathbf{C}\right)$} & \multicolumn{3}{c|}{ Precipitation $(\mathbf{m m})$} & \multicolumn{3}{c}{ Relative humidity $(\%)$} \\
\cline { 2 - 9 } & $\mathbf{2 0 1 0}$ & $\mathbf{2 0 1 1}$ & LTA & $\mathbf{2 0 1 0}$ & $\mathbf{2 0 1 1}$ & LTA & $\mathbf{2 0 1 0}$ & $\mathbf{2 0 1 1}$ & LTA \\
\hline April & 7.3 & 6.9 & 6.9 & 154.4 & 159.0 & 87.1 & 71.0 & 71.0 & 69.4 \\
May & 11.4 & 11.2 & 13.1 & 106.2 & 90.0 & 70.2 & 65.8 & 69.1 & 65.0 \\
June & 18.3 & 17.6 & 18.9 & 28.0 & 15.6 & 28.7 & 50.4 & 52.1 & 55.6 \\
July & 22.8 & 22.3 & 21.5 & 1.8 & 3.2 & 8.3 & 37.3 & 41.3 & 49.4 \\
August & 22.5 & 22.0 & 22.8 & 0.6 & 1.6 & 5.7 & 35.6 & 40.4 & 47.7 \\
\hline Season(M/T)* & 16.5 & 16.0 & 16.1 & 291.0 & 269.4 & 136.2 & 52.0 & 54.8 & 57.4 \\
Yearly(M/T) & 10.9 & 8.6 & 9.3 & 399.0 & 566.6 & 562.6 & 59.6 & 56.4 & 63.8 \\
\hline
\end{tabular}

* M: Mean, T: Total 


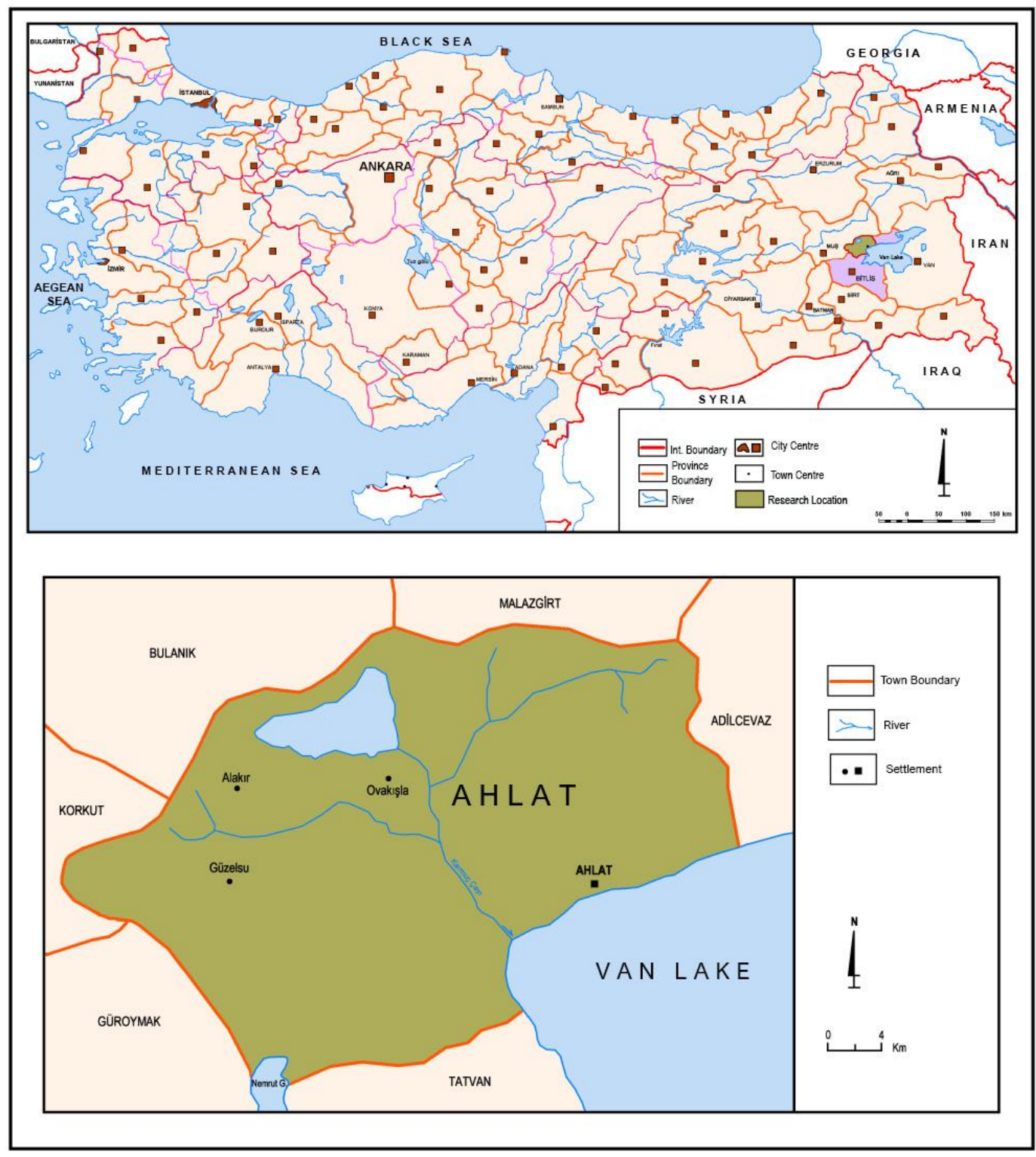

Figure 1. Map of study site

Prior to the experiments, soil samples were collected in the experiment site and analyzed for their physical and chemical properties using the methods described in Soil and Plant Analysis Laboratory Manual by Ryan et al. (2012). Soil samples were collected in the top $30 \mathrm{~cm}(<2 \mathrm{~mm}$ fraction) of soil at different locations of the experiment site. The experiment site soil was silt-clay-loam with a $\mathrm{pH}$ of 7.41 , total nitrogen content of $0.15 \mathrm{~g} \mathrm{~kg}^{-1}$, organic matter content of $1.60 \%, \mathrm{CaCO}_{3}$ content of $6.8 \%$, electrical conductivity of $1.16 \mathrm{dS} \mathrm{m}^{-1}$, available phosphorus content of $7.95 \mathrm{mg} \mathrm{kg}^{-1}$, available potassium content of $196 \mathrm{mg} \mathrm{kg}^{-1}$, available manganese content of $3.30 \mathrm{mg} \mathrm{kg}^{-1}$, zinc content of $1.44 \mathrm{mg} \mathrm{kg}^{-1}$, iron content of $5.85 \mathrm{mg} \mathrm{kg}^{-1}$ and copper content of $0.59 \mathrm{mg} \mathrm{kg}^{-1}$.

\section{Plant Material and Experimental Design}

Safflower (Carthamus tinctorius L.) var. Dincer, Turkey of origin, which exhibits early maturity, spineless, open-pollinated, yellow-orange flower color, white seed color, 
$28-32 \%$ oil content and high-linoleic oil type, was used as plant material. The field trials were set up a factorial design including the two following factors: four HA doses $\left(0=\right.$ without the addition of HA, $20=200 \mathrm{~kg} \mathrm{ha}^{-1} \mathrm{HA}, 30=300 \mathrm{~kg} \mathrm{ha}^{-1} \mathrm{HA}$ and $\left.40=400 \mathrm{~kg} \mathrm{ha}^{-1} \mathrm{HA}\right)$ and three PGPR applications ( $\mathrm{B} 0=$ no bacterial inoculation, B1: Bacillus subtilis OSU-142 and B2: Bacillus megatorium M3) with three replications.

\section{Humic Acid Characteristics, PGPR Culture Condition and Seed Inoculation}

Agro-Lig, a commercial product, was produced through crude humic acids derived from leonardite and provided by Altintar Chemicals Company (Turkey). Agro-Lig contains total humic acid 85\%, total organic matter 75\%, $\mathrm{pH} 3.5-5.5$, max moisture $22 \%$, silicon $0.5 \%$, iron $0.5 \%$, magnesium $0.5 \%$, calcium $3.0 \%$, sodium $0.3 \%$, manganese $0.02 \%$, copper $0.0003 \%$, potassium $0.07 \%$, titanium $0.02 \%$, barium $0.03 \%$, boron $0.01 \%$, cobalt $0.0002 \%$ dry matter basis. Three HA doses $(200,300$ and $400 \mathrm{~kg}$ $\mathrm{ha}^{-1}$ ) were prepared by Agro-Lig in granule form.

The two plant growth promoting rhizobacteria strains (Bacillus subtilis strain OSU-142 and Bacillus megatorium strain M3) tested were kindly procured at Atatürk University, Department of Plant Protection, Turkey. Currently, these strains are protected in culture collection unit in the Department of Genetic and Bioengineering, Faculty of Engineering at Yeditepe University, İstanbul, Turkey. The choice of these two bacteria is based on their published ability to act as potential biostimulants and biofertilizers. The gram-positive Bacillus megatorium M3 has demonstrated abilities to increase the solubilization of inorganic phosphates and to promote plant growth in various plant species (Cakmakci et al., 2001; Orhan et al., 2006). The gram-positive Bacillus subtilis OSU-142 is an efficient root colonizer and has been shown to $\mathrm{N}_{2}$-fixing under field conditions (Cakmakci et al., 2001, 2006). Moreover, it has widely shown the potential to improve plant growth and nitrogen acquisition when inoculated to various plant species (Cakmakci et al., 2001, 2006; Esitken et al., 2003; Orhan et al., 2006; Elkoca et al., 2010; Acikgoz et al., 2016; Ekin, 2019). These strains are indigenous, and are kept in nutrient broth (NB) with $15 \%$ glycerol at $-80^{\circ} \mathrm{C}$ for long-term storage, and grown on nutrient agar (NA) for routine use. Single colonies were transferred to $500 \mathrm{ml}$ flasks that contained NB and incubated aerobically on a rotating shaker $(150 \mathrm{rpm})$ overnight at $28^{\circ} \mathrm{C}$ (Cakmakci et al., 2001, 2006). The bacterial suspension was then diluted in sterilized water to final concentration at cell densities of $10^{9}$ colony forming units (CFU) $\mathrm{ml}^{-1}$. Seeds were surface sterilized prior to bacterial inoculation with $95 \%$ ethanol then sterilized with $10 \%$ chlorox for 3 min and washed successively 3-4 times with distilled water. Seeds were inoculated with the liquid cultures of rhizobacteria (Bacillus megatorium M3 and Bacillus subtilis OSU-142) mixed with 10\% sugar solution for $30 \mathrm{~min}$, and were stored overnight to dry under room temperature.

\section{Crop Husbandry and Data Recording}

The tillage system was fall plow and spring cultivate. Different doses of humic acid (granule form) were applied to the soil in humic acid treated plots, according to the layout. Humic acid was applied once during planting and then mixed well with the soil. PGPR inoculated and non-inoculated seeds were sown in early April in each year. In the present study, plots were $1.5 \mathrm{~m}$ wide and $5 \mathrm{~m}$ long and consisted of five rows spaced $0.3 \mathrm{~m}$ apart. Plot stands were over sown and hand-thinned approximately at the first four-true leaf stage to $10 \mathrm{~cm}$ apart within a row. Throughout the growth season, the production system was 
managed based on management practices recommended for the region, which included weed control by hand as required. The safflower plants were manually harvested at the stage of physiological maturity, when most of the leaves turn a brown color and very little green remains on the bracts of the latest flowering heads in late August in each year. Data collecting on the plant height $(\mathrm{cm})$, stem diameter $(\mathrm{mm})$, number of branches per plant, number of capitula per plant, number of seeds per capitulum and capitilum diameter $(\mathrm{cm})$ were recorded for ten randomly selected safflower plants in the central three rows of each plot. The seed yield was expressed in $\mathrm{t} \mathrm{ha}^{-1}$. The seed oil and total nitrogen contents were determined by Soxhlet extraction and Kjeldahl methods. Then, total $\mathrm{N}$ content was also used for the calculation of the seed protein concentration by multiplication with a conversion factor of 6.25 (Ryan et al., 2012). For mineral content analysis (P, K, Ca, Mg, $\mathrm{Fe}, \mathrm{Zn}, \mathrm{Cu}, \mathrm{Mn}$ ), safflower seed was ground in a Wiley Mill to pass through an $840-\mu \mathrm{m}$ screen and wet-digested in $\mathrm{HNO}_{3}: \mathrm{HClO}_{4}(6: 2 \mathrm{v} / \mathrm{v})$ with the Advanced Microwave Digestion System, Ethos Easy, then analyzed with the Inductively Coupled Plasma Optical Emission Spectrometry (iCAP 6000 SERIES, ICP Spectrometer).

\section{Data Analysis}

The data were tested for homogeneity and normality of residuals using the KolmogorovSmirnov and Bartlett tests, respectively. Afterwards, a combined analysis of variance (ANOVA) was used to compare the effects of humic acid doses and bacterial treatments by field experiment interactions for 2 years using PROC GLM of SAS 9. Mean comparisons were conducted using Fisher's least significant difference $\left(\mathrm{LSD}_{0.05}\right)$ test.

\section{Results}

\section{Morphological and Yield Parameters}

The results regarding morphological and yield parameters of safflower in relation to humic acid dose and plant growth promoting rhizobacteria inoculation are presented in Table 2. Highly significant increases were observed in safflower growth and yield parameters after inoculation with PGPR (Bacillus strains), and further improved after combined application with humic acid doses. When compared to plant growth promoting rhizobacteria treatments both with and without humic acids, it was observed that inoculation with Bacillus subtilis OSU-142 $\left(\mathrm{B}_{1}\right)$ was more effective when compared to Bacillus megatorium M3 $\left(\mathrm{B}_{2}\right)$. Furthermore, a significant interaction between the tested factors was observed in the case of stem diameter, number of branches and capitula per plant, number of seeds per capitilum, capitilum diameter and 1000 seed weight, whereas plant height was highly influenced by humic acid dose and plant growth promoting rhizobacteria inoculation with no significant HA x PGPR interaction (Table 2, Fig. 2). The tallest plant height values were recorded in both Bacillus subtilis OSU-142 inoculation and $400 \mathrm{~kg} \mathrm{ha}^{-1} \mathrm{HA}$ dose, while the highest numbers of capitula per plant and seeds per capitulum, largest capitilum diameter and 1000 seed weight values were recorded in co-application of Bacillus subtilis OSU-142 with 300 and 400 $\mathrm{kg} \mathrm{ha}^{-1} \mathrm{HA}$ doses $\left(\mathrm{HA}_{30}+\mathrm{B}_{1}\right.$ and $\left.\mathrm{HA}_{40}+\mathrm{B}_{1}\right)$. Likewise, the application of $400 \mathrm{~kg} \mathrm{ha}^{-1} \mathrm{HA}$ dose significantly increased numbers of branch per plant and seeds per capitulum at both $\mathrm{B}_{1}$ and $\mathrm{B}_{2}$ inoculation by $81.3 \%$ and $90.6 \%$ in branch numbers and $85.5 \%$ and $83.6 \%$ in seed numbers increases when compared to the untreated control plants, respectively (Table 2, Fig. 2). 
Table 2. Mean of morphological and yield traits of safflower affected by plant growth promoting rhizobacteria and humic acid doses ${ }^{1}$

\begin{tabular}{|c|c|c|c|c|c|c|c|}
\hline Treatments & $\begin{array}{l}\text { Plant } \\
\text { height } \\
\text { (cm) }\end{array}$ & $\begin{array}{c}\text { Stem } \\
\text { diameter } \\
(\mathbf{m m})\end{array}$ & \begin{tabular}{|c|} 
No. of \\
branches per \\
plant
\end{tabular} & $\begin{array}{c}\text { No. of } \\
\text { capitula per } \\
\text { plant }\end{array}$ & $\begin{array}{c}\text { No. of seeds } \\
\text { per capitulum }\end{array}$ & $\begin{array}{c}\text { Capitilum } \\
\text { diameter }(\mathrm{cm})\end{array}$ & $\begin{array}{l}1000 \text { seed } \\
\text { weight }(\mathrm{g})\end{array}$ \\
\hline \multicolumn{8}{|c|}{ Humic acid (HA) } \\
\hline 0 & $73.0 \mathrm{~d}$ & $5.64 \mathrm{c}$ & $4.3 \mathrm{~d}$ & $6.7 \mathrm{~d}$ & $25.5 \mathrm{~d}$ & $2.07 \mathrm{~b}$ & $33.1 \mathrm{~d}$ \\
\hline 20 & $77.4 \mathrm{c}$ & $6.70 \mathrm{~b}$ & $4.9 \mathrm{c}$ & $10.4 \mathrm{c}$ & $34.8 \mathrm{c}$ & $2.39 \mathrm{a}$ & $37.0 \mathrm{c}$ \\
\hline 30 & $82.7 \mathrm{~b}$ & $6.98 \mathrm{a}$ & $5.3 \mathrm{~b}$ & $10.9 \mathrm{~b}$ & $35.8 \mathrm{~b}$ & $2.39 \mathrm{a}$ & $38.1 \mathrm{~b}$ \\
\hline 40 & $85.2 \mathrm{a}$ & $7.05 \mathrm{a}$ & $5.9 \mathrm{a}$ & $11.3 \mathrm{a}$ & $36.7 \mathrm{a}$ & $2.40 \mathrm{a}$ & $38.5 \mathrm{a}$ \\
\hline $\mathrm{LSD}_{0,05}$ & 2.383 & 0.118 & 0.129 & 0.125 & 0.627 & 0.024 & 0.405 \\
\hline Significance & $* *$ & $* *$ & $* *$ & $* *$ & $* *$ & $* *$ & $* *$ \\
\hline \multicolumn{8}{|c|}{ Plant growth promoting rhizobacteria (PGPR) } \\
\hline $\mathrm{B}_{0}$ & $71.9 \mathrm{c}$ & $6.18 \mathrm{c}$ & $4.6 \mathrm{c}$ & $8.4 \mathrm{c}$ & $30.4 \mathrm{c}$ & $2.20 \mathrm{c}$ & $34.6 \mathrm{c}$ \\
\hline $\mathrm{B}_{1}$ & $87.6 \mathrm{a}$ & $6.91 \mathrm{a}$ & $5.6 \mathrm{a}$ & $11.3 \mathrm{a}$ & $35.6 \mathrm{a}$ & $2.41 \mathrm{a}$ & $38.5 \mathrm{a}$ \\
\hline $\mathrm{B}_{2}$ & $79.2 \mathrm{~b}$ & $6.70 \mathrm{~b}$ & $5.1 \mathrm{~b}$ & $10.0 \mathrm{~b}$ & $33.8 \mathrm{~b}$ & $2.32 \mathrm{~b}$ & $37.0 \mathrm{~b}$ \\
\hline $\mathrm{LSD}_{0,05}$ & 2.064 & 1.102 & 0.112 & 0.108 & 0.543 & 0.021 & 0.350 \\
\hline Significance & $* *$ & $* *$ & $* *$ & $* *$ & $* *$ & $* *$ & $* *$ \\
\hline \multicolumn{8}{|c|}{ HA x PGPR } \\
\hline $\mathrm{HA}_{0}+\mathrm{B}_{0}$ & 66.6 & $4.56 \mathrm{~g}$ & $3.2 \mathrm{e}$ & $4.9 \mathrm{j}$ & $20.7 \mathrm{~g}$ & $1.90 \mathrm{f}$ & $29.2 \mathrm{~g}$ \\
\hline $\mathrm{HA}_{0}+\mathrm{B}_{1}$ & 79.9 & $6.40 \mathrm{e}$ & $4.9 \mathrm{c}$ & $8.6 \mathrm{~h}$ & $29.0 \mathrm{e}$ & $2.20 \mathrm{~d}$ & $36.0 \mathrm{e}$ \\
\hline $\mathrm{HA}_{0}+\mathrm{B}_{2}$ & 71.8 & $5.78 \mathrm{f}$ & $4.5 \mathrm{~d}$ & 6.31 & $26.2 \mathrm{f}$ & $2.09 \mathrm{e}$ & $33.7 \mathrm{f}$ \\
\hline $\mathrm{HA}_{20}+\mathrm{B}_{0}$ & 69.7 & $6.40 \mathrm{e}$ & $4.3 \mathrm{~d}$ & $8.9 \mathrm{~g}$ & $32.3 \mathrm{~d}$ & $2.31 \mathrm{c}$ & $35.5 \mathrm{e}$ \\
\hline $\mathrm{HA}_{20}+\mathrm{B}_{1}$ & 85.3 & $6.80 \mathrm{~d}$ & $5.4 \mathrm{~b}$ & $11.5 \mathrm{~b}$ & $37.1 \mathrm{ab}$ & $2.46 \mathrm{a}$ & $38.2 \mathrm{c}$ \\
\hline $\mathrm{HA}_{20}+\mathrm{B}_{2}$ & 77.4 & $6.90 \mathrm{~d}$ & $4.9 \mathrm{c}$ & $10.9 \mathrm{~d}$ & $34.9 \mathrm{c}$ & $2.40 \mathrm{~b}$ & $37.3 \mathrm{~d}$ \\
\hline $\mathrm{HA}_{30}+\mathrm{B}_{0}$ & 73.9 & $6.71 \mathrm{~d}$ & $4.7 \mathrm{~d}$ & $9.2 \mathrm{f}$ & $33.1 \mathrm{~d}$ & $2.29 \mathrm{c}$ & $36.1 \mathrm{e}$ \\
\hline $\mathrm{HA}_{30}+\mathrm{B}_{1}$ & 92.9 & $7.11 \mathrm{~b}$ & $6.1 \mathrm{a}$ & $12.5 \mathrm{a}$ & $38.2 \mathrm{a}$ & $2.51 \mathrm{a}$ & $40.0 \mathrm{a}$ \\
\hline $\mathrm{HA}_{30}+\mathrm{B}_{2}$ & 81.4 & $7.11 \mathrm{~b}$ & $5.0 \mathrm{c}$ & $11.1 \mathrm{c}$ & $36.3 \mathrm{~b}$ & $2.36 \mathrm{~b}$ & $38.1 \mathrm{c}$ \\
\hline $\mathrm{HA}_{40}+\mathrm{B}_{0}$ & 76.5 & $6.78 \mathrm{~d}$ & $5.8 \mathrm{a}$ & $10.3 \mathrm{e}$ & $34.1 \mathrm{c}$ & $2.28 \mathrm{c}$ & $36.8 \mathrm{~d}$ \\
\hline $\mathrm{HA}_{40}+\mathrm{B}_{1}$ & 92.5 & $7.33 \mathrm{a}$ & $6.1 \mathrm{a}$ & $12.6 \mathrm{a}$ & $38.4 \mathrm{a}$ & $2.48 \mathrm{a}$ & $39.8 \mathrm{a}$ \\
\hline $\mathrm{HA}_{40}+\mathrm{B}_{2}$ & 86.6 & $7.03 \mathrm{c}$ & $5.8 \mathrm{a}$ & $11.7 \mathrm{~b}$ & $38.0 \mathrm{a}$ & $2.41 \mathrm{~b}$ & $39.0 \mathrm{~b}$ \\
\hline Significance & $\mathrm{ns}$ & $* *$ & $* *$ & $* *$ & $* *$ & $* *$ & $* *$ \\
\hline CV (\%) & 4.38 & 2.62 & 3.70 & 1.84 & 2.79 & 1.53 & 1.61 \\
\hline
\end{tabular}

${ }^{1} 20,30$ and 40 treatments refer to safflower plants growing under field condition with 200, 300 and $400 \mathrm{~kg} \mathrm{ha}^{-1}$ of HA; $\mathrm{B}_{0}$ treatment without any application of the bacteria, $\mathrm{B}_{1}$ treatment with Bacillus subtilis OSU-142 inoculation; $\mathrm{B}_{1}+20, \mathrm{~B}_{1}+30$, and $\mathrm{B}_{1}+40$ with Bacillus subtilis OSU-142 and 200, 300 and $400 \mathrm{~kg} \mathrm{ha}^{-1}$ of $\mathrm{HA}$, respectively; $\mathrm{B}_{2}$ treatment with Bacillus megatorium M3 inoculation; $\mathrm{B}_{2}+20$, $\mathrm{B}_{2}+30$, and $\mathrm{B}_{2}+40$ with Bacillus megatorium M3 and 200, 300 and $400 \mathrm{~kg} \mathrm{ha}^{-1}$ of HA, respectively. Means followed by different letters are different by LSD test. *: $\mathrm{P}<0.05$, **: $\mathrm{P}<0.01$, ns: not significant; CV: coefficient of variations

\section{Seed Yield and Quality Parameters}

Seed, oil and protein yields and certain quality parameters of safflower were significantly affected by plant growth promoting rhizobacteria and humic acid treatments based on the two-year average data (Table 3). For most of the measured quality parameters, no significant interaction between plant growth promoting rhizobacteria and humic acid application was recorded, except for the seed yield and fertile and sterile seed ratio (Table 3, Fig. 3). 


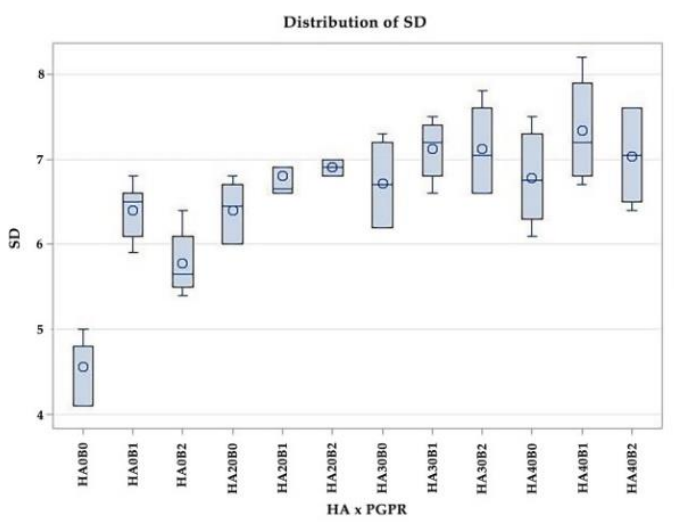

(a)

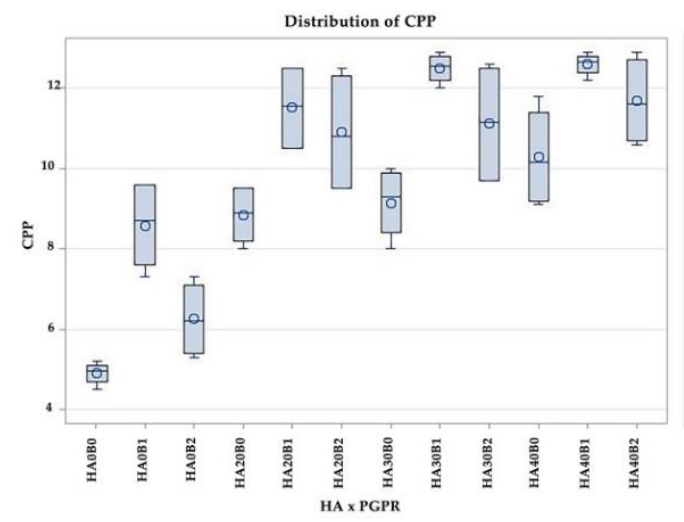

(c)

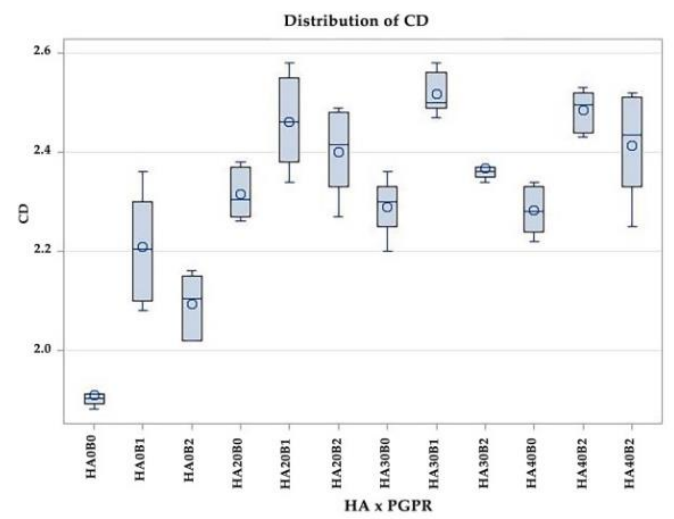

(e)

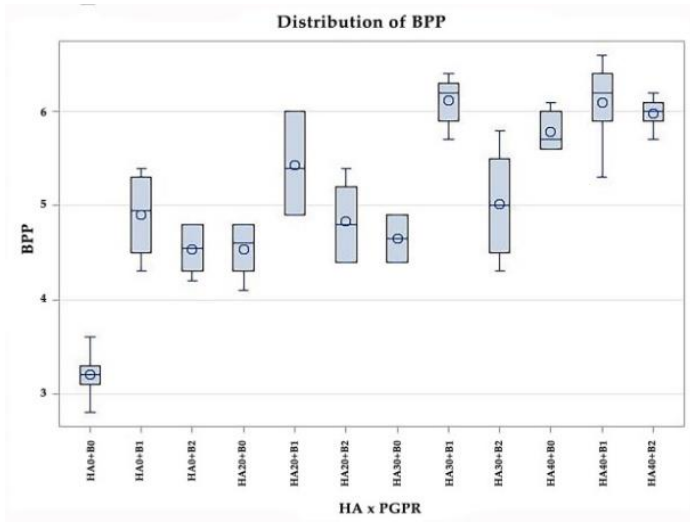

(b)

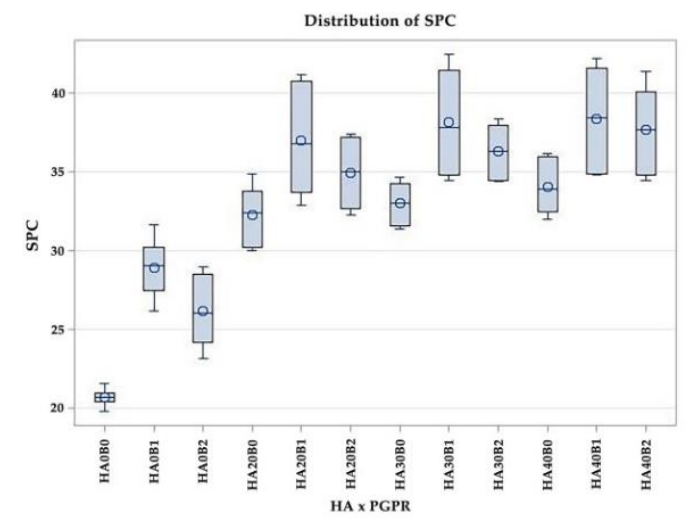

(d)

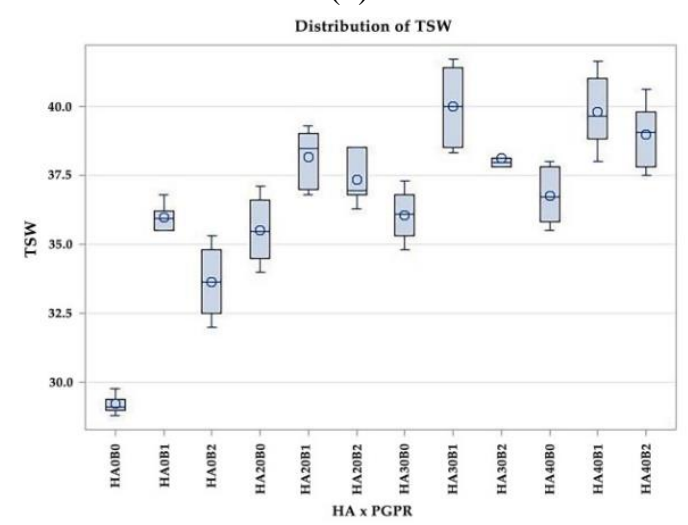

(f)

Figure 2. Stem diameter (mm) (a), number of branch per plant $(\boldsymbol{b})$, number of capitula per plant $(\boldsymbol{c})$, number of seeds per capitilum $(\boldsymbol{d})$, capitilum diameter $(\mathrm{cm})(\boldsymbol{e})$ and thousand seed weight $(g)(f)$ of safflower affected by bacterial inoculation and humic acid. $B_{0}$ : without bacteria; $B_{1}: B$. subtilis OSU-142; $B_{1}+20, B_{1}+30$, and $B_{1}+40:$ B. subtilis OSU-142 with 200, 300 and $400 \mathrm{~kg}$ $h a^{-1}$ of $H A$, respectively; $B_{2}: B$. megatorium $M 3 ; B_{2}+20, B_{2}+30$ and $B_{2}+40: B$. megatorium $M 3$ with 200, 300 and $400 \mathrm{~kg} \mathrm{ha}^{-1}$ of $\mathrm{HA}$, respectively

Fertile and sterile seed percentages, the most important quality characteristics for safflower, were significantly affected by both plant growth promoting rhizobacteria and humic acid treatments; however, its co-application significantly reduced sterile seed percentage, whereas an opposite trend was observed for the fertile seed percentage (Table 3). The highest fertile seed and lowest sterile seed percentages were recorded in co-application of 


$$
-1891 \text { - }
$$

both PGPR strains with $300 \mathrm{~kg} \mathrm{ha}^{-1}$ humic acid dose $\left(\mathrm{HA}_{30}+\mathrm{B}_{1}\right.$ and $\left.\mathrm{HA}_{30}+\mathrm{B}_{2}\right)$, whose values were higher by 9.0 and $8.6 \%$ and lower by $85.1 \%$ and $79.9 \%$, respectively, compared to the untreated control. In the present study, a significant interaction between the tested factors was also observed for the seed yield (Table 3). Inoculation with Bacillus subtilis OSU-142 triggered ameliorative effects in terms of seed yield at both 300 and $400 \mathrm{~kg} \mathrm{ha}^{-1}$ humic acid doses and led to an increase in seed yield by $163.6 \%$ and $161.4 \%$, respectively, when compared to the control (Table 3, Fig. 3). Furthermore, its effect was much more pronounced than that of inoculation with Bacillus megatorium M3. Among the humic acid doses, the highest seed yields were also recorded with the application of 300 and $400 \mathrm{~kg} \mathrm{ha}^{-1}$ humic acid doses which was statistically similar (Table 3).

Table 3. Mean of seed yield and certain quality traits of safflower affected by plant growth promoting rhizobacteria and humic acid doses ${ }^{l}$

\begin{tabular}{|c|c|c|c|c|c|c|c|}
\hline \multirow{2}{*}{ Treatments } & \multicolumn{2}{|c|}{ Seed ratio $(\%)$} & \multicolumn{2}{|c|}{ Seed content $(\%)$} & \multicolumn{3}{|c|}{ Yield $\left(\mathrm{t} \mathrm{ha}^{-1}\right)$} \\
\hline & Fertile & Sterile & Oil & Protein & Seed & Oil & Protein \\
\hline \multicolumn{8}{|c|}{ Humic acid (HA) } \\
\hline 0 & $92.72 \mathrm{~d}$ & $7.27 \mathrm{a}$ & $27.1 \mathrm{c}$ & 13.9 & $1.22 \mathrm{c}$ & $0.33 \mathrm{c}$ & $0.16 \mathrm{~b}$ \\
\hline 20 & $94.90 \mathrm{c}$ & $4.17 \mathrm{c}$ & $29.0 \mathrm{bc}$ & 13.6 & $1.74 \mathrm{~b}$ & $0.51 \mathrm{~b}$ & $0.24 \mathrm{a}$ \\
\hline 30 & $95.89 \mathrm{~b}$ & $2.25 \mathrm{~d}$ & $30.7 \mathrm{ab}$ & 13.2 & $1.95 \mathrm{a}$ & $0.59 \mathrm{a}$ & $0.25 \mathrm{a}$ \\
\hline 40 & $97.75 \mathrm{a}$ & $5.10 \mathrm{~b}$ & $31.3 \mathrm{a}$ & 12.8 & $2.01 \mathrm{a}$ & $0.62 \mathrm{a}$ & $0.26 \mathrm{a}$ \\
\hline $\mathrm{LSD}_{0,05}$ & 0.745 & 0.751 & 2.186 & 1.438 & 0.149 & 0.022 & 0.051 \\
\hline Significance & $* *$ & $* *$ & $* *$ & ns & $* *$ & $* *$ & $* *$ \\
\hline \multicolumn{8}{|c|}{ Plant growth promoting rhizobacteria (PGPR) } \\
\hline $\mathrm{B}_{0}$ & $94.24 \mathrm{~b}$ & $5.78 \mathrm{a}$ & $27.7 \mathrm{~b}$ & 12.7 & $1.40 \mathrm{c}$ & $0.39 \mathrm{c}$ & $0.19 \mathrm{c}$ \\
\hline $\mathrm{B}_{1}$ & $95.62 \mathrm{a}$ & $4.38 \mathrm{~b}$ & $30.5 \mathrm{a}$ & 13.8 & $2.06 \mathrm{a}$ & $0.63 \mathrm{a}$ & $0.28 \mathrm{a}$ \\
\hline $\mathrm{B}_{2}$ & $96.15 \mathrm{a}$ & $3.89 \mathrm{~b}$ & $30.4 \mathrm{a}$ & 13.5 & $1.73 \mathrm{~b}$ & $0.52 \mathrm{~b}$ & $0.22 \mathrm{~b}$ \\
\hline $\mathrm{LSD}_{0,05}$ & 0.645 & 0.651 & 1.892 & 1.245 & 0.174 & 0.052 & 0.034 \\
\hline Significance & $* *$ & $* *$ & $* *$ & ns & $* *$ & $* *$ & $* *$ \\
\hline \multicolumn{8}{|c|}{ HA x PGPR } \\
\hline $\mathrm{HA}_{0}+\mathrm{B}_{0}$ & $90.37 \mathrm{~d}$ & $9.85 \mathrm{a}$ & 25.7 & 14.0 & $0.88 \mathrm{~h}$ & 0.23 & 0.12 \\
\hline $\mathrm{HA}_{0}+\mathrm{B}_{1}$ & $94.22 b c$ & $5.77 \mathrm{bc}$ & 27.1 & 14.1 & $1.56 \mathrm{ef}$ & 0.42 & 0.22 \\
\hline $\mathrm{HA}_{0}+\mathrm{B}_{2}$ & $93.17 \mathrm{c}$ & $6.82 \mathrm{~b}$ & 28.3 & 13.5 & $1.15 \mathrm{~g}$ & 0.33 & 0.15 \\
\hline $\mathrm{HA}_{20}+\mathrm{B}_{0}$ & $93.98 \mathrm{c}$ & $6.02 \mathrm{~b}$ & 26.8 & 13.9 & $1.41 \mathrm{f}$ & 0.37 & 0.19 \\
\hline $\mathrm{HA}_{20}+\mathrm{B}_{1}$ & $95.77 \mathrm{~b}$ & $4.22 \mathrm{c}$ & 30.6 & 14.0 & $2.05 \mathrm{~b}$ & 0.62 & 0.29 \\
\hline $\mathrm{HA}_{20}+\mathrm{B}_{2}$ & $97.92 \mathrm{a}$ & $2.25 \mathrm{~cd}$ & 29.8 & 12.9 & $1.76 \mathrm{~d}$ & 0.52 & 0.23 \\
\hline $\mathrm{HA}_{30}+\mathrm{B}_{0}$ & $96.70 \mathrm{ab}$ & $3.29 \mathrm{c}$ & 28.3 & 13.3 & $1.60 \mathrm{e}$ & 0.45 & 0.21 \\
\hline $\mathrm{HA}_{30}+\mathrm{B}_{1}$ & $98.52 \mathrm{a}$ & $1.47 \mathrm{~d}$ & 32.4 & 13.8 & $2.32 \mathrm{a}$ & 0.75 & 0.31 \\
\hline $\mathrm{HA}_{30}+\mathrm{B}_{2}$ & $98.03 \mathrm{a}$ & $1.98 \mathrm{~d}$ & 31.4 & 12.5 & $1.93 \mathrm{c}$ & 0.59 & 0.25 \\
\hline $\mathrm{HA}_{40}+\mathrm{B}_{0}$ & $95.25 \mathrm{~b}$ & $4.74 \mathrm{c}$ & 29.9 & 13.1 & $16.4 \mathrm{e}$ & 0.48 & 0.21 \\
\hline $\mathrm{HA}_{40}+\mathrm{B}_{1}$ & $93.95 \mathrm{c}$ & $6.04 \mathrm{~b}$ & 31.5 & 13.2 & $2.30 \mathrm{a}$ & 0.73 & 0.31 \\
\hline $\mathrm{HA}_{40}+\mathrm{B}_{2}$ & $95.50 \mathrm{~b}$ & $4.50 \mathrm{c}$ & 32.4 & 11.9 & $2.06 \mathrm{~b}$ & 0.66 & 0.24 \\
\hline Significance & $* *$ & $* *$ & ns & $\mathrm{ns}$ & $*$ & $\mathrm{~ns}$ & $\mathrm{~ns}$ \\
\hline $\mathrm{CV}(\%)$ & 1.15 & 13.64 & 5.84 & 4.80 & 7.32 & 4.84 & 7.50 \\
\hline
\end{tabular}

${ }^{1} 20,30$ and 40 treatments refer to safflower plants growing under field condition with 200,300 and $400 \mathrm{~kg} \mathrm{ha}^{-1}$ of HA; $\mathrm{B}_{0}$ treatment without any application of the bacteria, $\mathrm{B}_{1}$ treatment with Bacillus subtilis OSU-142 inoculation; $\mathrm{B}_{1}+20, \mathrm{~B}_{1}+30$, and $\mathrm{B}_{1}+40$ with Bacillus subtilis OSU-142 and 200, 300 and $400 \mathrm{~kg} \mathrm{ha}^{-1}$ of HA, respectively; $\mathrm{B}_{2}$ treatment with Bacillus megatorium M3 inoculation; $\mathrm{B}_{2}+20$, $\mathrm{B}_{2}+30$, and $\mathrm{B}_{2}+40$ with Bacillus megatorium M3 and 200, 300 and $400 \mathrm{~kg} \mathrm{ha}^{-1}$ of HA, respectively. Means followed by different letters are different by LSD test. *: $\mathrm{P}<0.05$, **: $\mathrm{P}<0.01$, ns: not significant; $\mathrm{CV}$ : coefficient of variations 


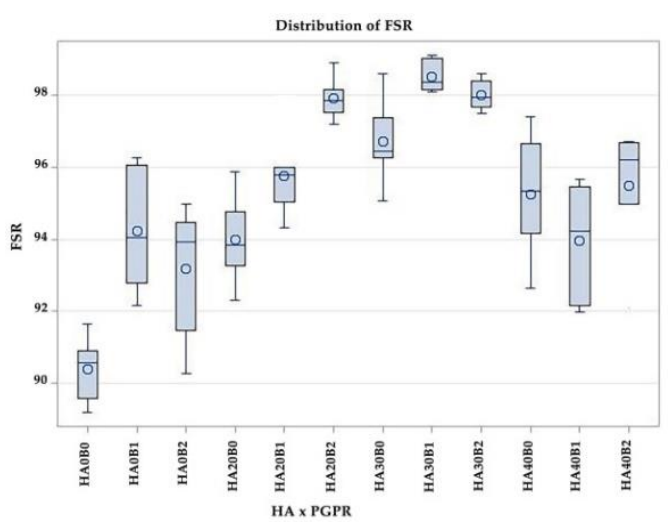

(a)

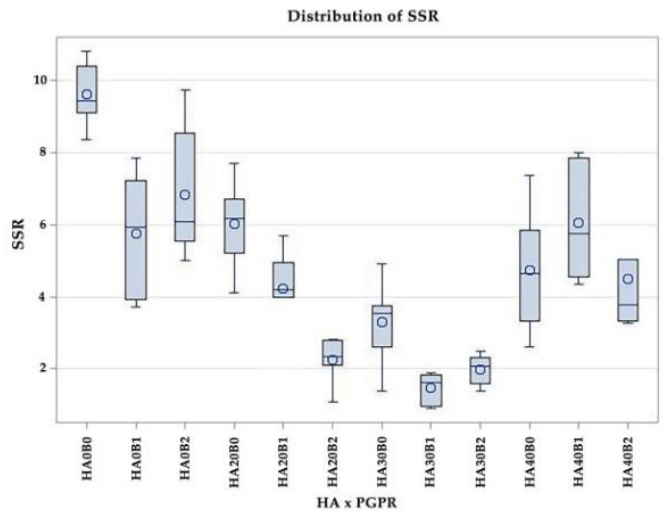

(b)

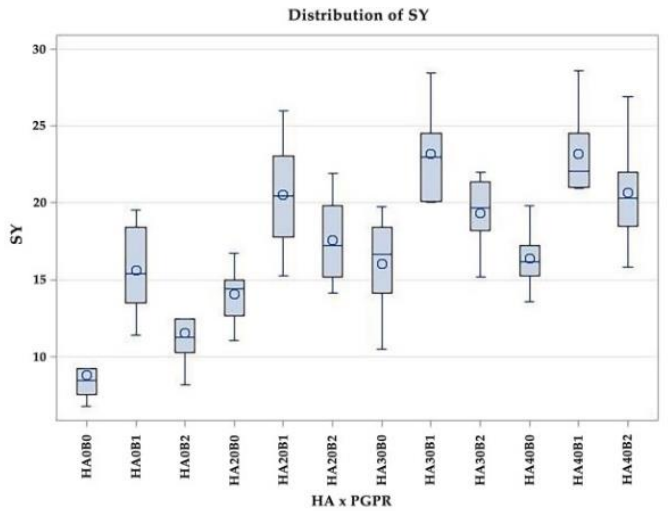

(c)

Figure 3. Fertile seed ratio (\%) (a), Sterile seed ratio (\%) $(\boldsymbol{b})$ and seed yield $\left(t h a^{-1}\right)(\boldsymbol{c})$ of safflower affected by bacterial inoculation and humic acid. $B_{0}$ : without bacteria; $B_{1}$ : B. subtilis OSU-142; $B_{1}+20, B_{1}+30$, and $B_{1}+40:$ B. subtilis OSU-142 with 200, 300 and $400 \mathrm{~kg} \mathrm{ha}^{-1}$ of $H A$, respectively; $B_{2}$ : B. megatorium $M 3 ; B_{2}+20, B_{2}+30$ and $B_{2}+40:$ B. megatorium M3 with 200, 300 and $400 \mathrm{~kg} \mathrm{ha}^{-1}$ of $\mathrm{HA}$, respectively

Neither humic acid doses nor plant growth promoting rhizobacteria inoculation had a significant influence on protein content in seeds, whereas seed oil concentration, oil and protein yields were highly influenced by humic acid dose and PGPR application with no significant HA x PGPR interaction (Table 3, Fig. 2). The oil concentration in seeds was positively affected by increasing the humic acid doses with no significant effect for inoculation with $\mathrm{B}_{1}$ and $\mathrm{B}_{2}$ (30.5\% and $30.4 \%$, respectively), and the highest value by $31.3 \%$ was recorded with $400 \mathrm{~kg} \mathrm{ha}^{-1}$ humic acid application (Table 3). However, significant increases in oil and protein yields were obtained with separate 300 and $400 \mathrm{~kg} \mathrm{ha}^{-1}$ humic acid dose and Bacillus subtilis OSU-142 applications (Table 3).

\section{Mineral Composition of Seeds}

The two years long field trials demonstrated that safflower seed mineral composition was significantly affected by both plant growth promoting rhizobacteria and humic acid treatments, however, these integrated administrations significantly increased the mineral concentrations in seeds (except for $\mathrm{Cu}$ ) when compared to single treatments (Table 4). The $\mathrm{Cu}$ concentration in seeds was only negatively affected by both increasing humic acid doses and inoculation with PGPR strains. 
Table 4. Mean of mineral composition $\left(\mathrm{mg} \mathrm{kg}^{-1}\right)$ of safflower seeds affected by plant growth promoting rhizobacteria and humic acid doses ${ }^{l}$

\begin{tabular}{|c|c|c|c|c|c|c|c|c|}
\hline Treatments & $\mathbf{P}$ & $\mathbf{K}$ & $\mathbf{C a}$ & Mg & $\mathbf{F e}$ & $\mathbf{Z n}$ & $\mathbf{C u}$ & Mn \\
\hline \multicolumn{9}{|c|}{ Humic acid (HA) } \\
\hline 0 & $3789.5 \mathrm{~d}$ & $3687.7 \mathrm{~d}$ & $2026.7 \mathrm{~d}$ & $1235.1 \mathrm{~d}$ & $49.21 \mathrm{~d}$ & $30.81 \mathrm{c}$ & $15.59 \mathrm{a}$ & $11.09 \mathrm{~b}$ \\
\hline 20 & $4181.7 \mathrm{c}$ & $4128.3 \mathrm{c}$ & $2384.5 \mathrm{c}$ & $1391.9 \mathrm{c}$ & $54.14 \mathrm{c}$ & $34.66 \mathrm{~b}$ & $15.42 \mathrm{ab}$ & $12.12 \mathrm{a}$ \\
\hline 30 & $4394.9 \mathrm{~b}$ & $4299.9 \mathrm{~b}$ & $2519.5 \mathrm{~b}$ & $1510.6 \mathrm{a}$ & $58.88 \mathrm{~b}$ & $35.71 \mathrm{a}$ & $15.04 \mathrm{~b}$ & $12.08 \mathrm{a}$ \\
\hline 40 & $4506.2 \mathrm{a}$ & $4374.4 \mathrm{a}$ & $2710.3 \mathrm{a}$ & $1475.4 \mathrm{~b}$ & $61.43 \mathrm{a}$ & $35.97 \mathrm{a}$ & $14.41 \mathrm{c}$ & $12.45 \mathrm{a}$ \\
\hline $\mathrm{LSD}_{0,05}$ & 21.658 & 32.421 & 17.067 & 5.777 & 0.506 & 0.455 & 0.390 & 0.399 \\
\hline Significance & $* *$ & $* *$ & $* *$ & $* *$ & $* *$ & $* *$ & $* *$ & $* *$ \\
\hline \multicolumn{9}{|c|}{ Plant growth promoting rhizobacteria (PGPR) } \\
\hline $\mathrm{B}_{0}$ & $3456.8 \mathrm{c}$ & $3800.9 \mathrm{c}$ & $2215.0 \mathrm{c}$ & $1194.4 \mathrm{c}$ & $51.40 \mathrm{c}$ & $31.10 \mathrm{~b}$ & $16.00 \mathrm{a}$ & $11.10 \mathrm{c}$ \\
\hline $\mathrm{B}_{1}$ & $4161.9 \mathrm{~b}$ & $4356.6 \mathrm{a}$ & $2533.1 \mathrm{a}$ & $1593.0 \mathrm{a}$ & $60.20 \mathrm{a}$ & $35.69 \mathrm{a}$ & $14.41 \mathrm{c}$ & $12.82 \mathrm{a}$ \\
\hline $\mathrm{B}_{2}$ & $5042.1 \mathrm{a}$ & $4210.1 \mathrm{~b}$ & $2482.5 \mathrm{~b}$ & $1422.3 \mathrm{~b}$ & $56.26 \mathrm{~b}$ & $36.08 \mathrm{a}$ & $14.97 \mathrm{~b}$ & $11.89 \mathrm{~b}$ \\
\hline $\mathrm{LSD}_{0,05}$ & 18.757 & 28.077 & 14.780 & 5.003 & 0.439 & 0.394 & 0.338 & 0.345 \\
\hline Significance & $* *$ & $* *$ & $* *$ & $* *$ & $* *$ & $* *$ & $* *$ & $* *$ \\
\hline \multicolumn{9}{|c|}{ HA x PGPR } \\
\hline $\mathrm{HA}_{0}+\mathrm{B}_{0}$ & $2743.0 \mathrm{k}$ & $2883.3 \mathrm{~g}$ & $1763.1 \mathrm{j}$ & $940.4 \mathrm{j}$ & $39.77 \mathrm{~h}$ & $21.19 \mathrm{~d}$ & 16.69 & $9.50 \mathrm{~d}$ \\
\hline $\mathrm{HA}_{0}+\mathrm{B}_{1}$ & $3959.1 \mathrm{~g}$ & $4133.2 \mathrm{~d}$ & 2094.71 & $1430.9 \mathrm{e}$ & $54.61 \mathrm{e}$ & $35.66 \mathrm{a}$ & 14.74 & $12.07 \mathrm{~b}$ \\
\hline $\mathrm{HA}_{0}+\mathrm{B}_{2}$ & $4693.2 \mathrm{~d}$ & $4046.6 \mathrm{e}$ & $2222.1 \mathrm{~g}$ & $1334.2 \mathrm{~g}$ & $51.68 \mathrm{~g}$ & $34.14 \mathrm{~b}$ & 15.54 & $11.44 \mathrm{~b}$ \\
\hline $\mathrm{HA}_{20}+\mathrm{B}_{0}$ & $3527.7 \mathrm{j}$ & $3974.1 \mathrm{f}$ & $2166.4 \mathrm{~h}$ & $1236.5 \mathrm{I}$ & $51.10 \mathrm{~g}$ & $34.83 \mathrm{~b}$ & 16.29 & $11.83 \mathrm{~b}$ \\
\hline $\mathrm{HA}_{20}+\mathrm{B}_{1}$ & $4083.3 \mathrm{f}$ & $4264.5 \mathrm{c}$ & $2557.8 \mathrm{~d}$ & $1553.4 \mathrm{c}$ & $57.88 \mathrm{~d}$ & $36.97 \mathrm{a}$ & 14.77 & $12.03 \mathrm{~b}$ \\
\hline $\mathrm{HA}_{20}+\mathrm{B}_{2}$ & $4933.8 \mathrm{c}$ & $4146.3 \mathrm{~d}$ & $2429.0 \mathrm{f}$ & $1385.9 \mathrm{f}$ & $53.45 \mathrm{f}$ & $36.10 \mathrm{a}$ & 15.21 & $12.49 \mathrm{~b}$ \\
\hline $\mathrm{HA}_{30}+\mathrm{B}_{0}$ & 3701.51 & $4116.8 \mathrm{~d}$ & $2441.7 \mathrm{f}$ & $1327.4 \mathrm{~g}$ & $54.82 \mathrm{e}$ & $34.05 \mathrm{~b}$ & 15.92 & $10.98 \mathrm{c}$ \\
\hline $\mathrm{HA}_{30}+\mathrm{B}_{1}$ & $4306.4 \mathrm{e}$ & $4530.5 \mathrm{a}$ & $2607.0 \mathrm{c}$ & $1685.4 \mathrm{~b}$ & $63.14 \mathrm{~b}$ & $36.38 \mathrm{a}$ & 14.40 & $13.49 \mathrm{a}$ \\
\hline $\mathrm{HA}_{30}+\mathrm{B}_{2}$ & $5176.5 \mathrm{~b}$ & $4252.4 \mathrm{c}$ & $2510.1 \mathrm{e}$ & $1519.0 \mathrm{~d}$ & $58.69 \mathrm{~d}$ & $36.69 \mathrm{a}$ & 14.78 & $11.77 \mathrm{~b}$ \\
\hline $\mathrm{HA}_{40}+\mathrm{B}_{0}$ & $3854.6 \mathrm{~h}$ & $4229.5 \mathrm{c}$ & $2488.6 \mathrm{e}$ & $1273.4 \mathrm{~h}$ & $57.95 \mathrm{~d}$ & $32.84 \mathrm{c}$ & 15.22 & $11.81 \mathrm{~b}$ \\
\hline $\mathrm{HA}_{40}+\mathrm{B}_{1}$ & $4298.9 \mathrm{e}$ & $4498.4 \mathrm{a}$ & $2873.2 \mathrm{a}$ & $1702.6 \mathrm{a}$ & $65.15 \mathrm{a}$ & $33.76 \mathrm{~b}$ & 13.69 & $13.68 \mathrm{a}$ \\
\hline $\mathrm{HA}_{40}+\mathrm{B}_{2}$ & $5364.8 \mathrm{a}$ & $4395.2 \mathrm{~b}$ & $2769.1 \mathrm{~b}$ & $1450.3 \mathrm{e}$ & $61.20 \mathrm{c}$ & $37.38 \mathrm{a}$ & 14.32 & $11.87 \mathrm{~b}$ \\
\hline Significance & $* *$ & $* *$ & $* *$ & $* *$ & $* *$ & $* *$ & ns & $* *$ \\
\hline $\mathrm{CV}(\%)$ & 1.76 & 2.16 & 2.07 & 1.60 & 2.32 & 2.94 & 3.78 & 4.89 \\
\hline
\end{tabular}

${ }^{1} 20,30$ and 40 treatments refer to safflower plants growing under field condition with 200, 300 and $400 \mathrm{~kg} \mathrm{ha}^{-1}$ of HA; $\mathrm{B}_{0}$ treatment without any application of the bacteria, $\mathrm{B}_{1}$ treatment with Bacillus subtilis OSU-142 inoculation; $\mathrm{B}_{1}+20, \mathrm{~B}_{1}+30$, and $\mathrm{B}_{1}+40$ with Bacillus subtilis OSU-142 and 200, 300 and $400 \mathrm{~kg} \mathrm{ha}^{-1}$ of HA, respectively; $\mathrm{B}_{2}$ treatment with Bacillus megatorium M3 inoculation; $\mathrm{B}_{2}+20$, $\mathrm{B}_{2}+30$, and $\mathrm{B}_{2}+40$ with Bacillus megatorium M3 and 200, 300 and $400 \mathrm{~kg} \mathrm{ha}^{-1}$ of HA, respectively. Means followed by different letters are different by LSD test. *: $\mathrm{P}<0.05$, **: $\mathrm{P}<0.01$, ns: not significant; CV: coefficient of variations

The study results indicated that increasing the humic acid dose from $200 \mathrm{~kg} \mathrm{ha}^{-1}$ to $400 \mathrm{~kg}$ $\mathrm{ha}^{-1}$ was accompanied by a linear increase in important mineral contents such as the $\mathrm{P}, \mathrm{K}, \mathrm{Ca}$ and $\mathrm{Fe}$ (Table 4). Furthermore, plant growth promoting rhizobacteria inoculation significantly improved in these contents after combined application with humic acid dose. The highest $\mathrm{P}$ concentration was obtained with Bacillus megatorium M3 bacterial treatment in $400 \mathrm{~kg} \mathrm{ha}^{-1}$ humic acid dose by $95.6 \%$ increase when compared to control, while the highest $\mathrm{K}, \mathrm{Ca}, \mathrm{Mg}$, Fe and Mn concentrations were recorded with the $400 \mathrm{~kg} \mathrm{ha}^{-1}$ humic acid dose with Bacillus subtilis OSU-142 bacterial inoculation $(56.1 \%, 62.9 \%, 81.1 \%, 63.8 \%$ and $44.0 \%$ increases in $\mathrm{K}, \mathrm{Ca}, \mathrm{Mg}, \mathrm{Fe}$ and $\mathrm{Mn}$ when compared to control, respectively). For $\mathrm{Zn}$ concentration, a significant interaction between the HA and PGPR factors was observed, where the inoculation with plant growth promoting rhizobacteria strains in all of humic acid doses significantly increased $\mathrm{Zn}$ accumulation in seed about $68.3 \%-76.4 \%$, compared to untreated safflower plants (Table 4, Fig. 4). 


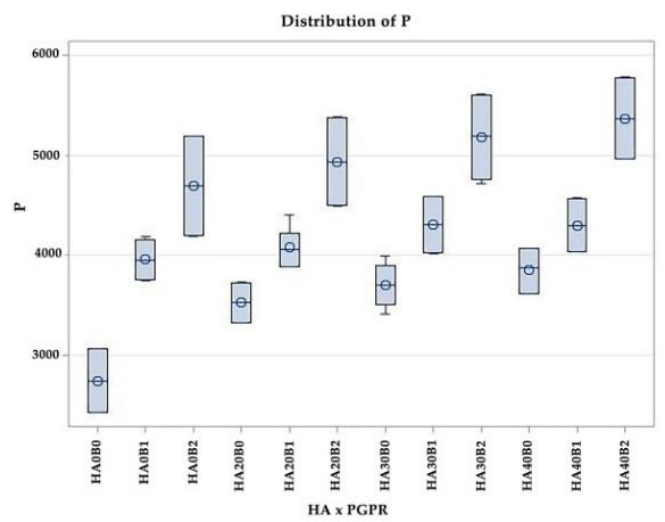

(a)

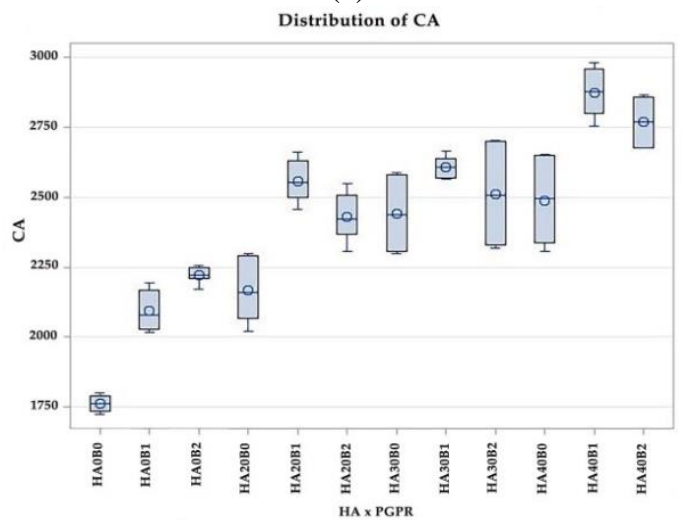

(c)

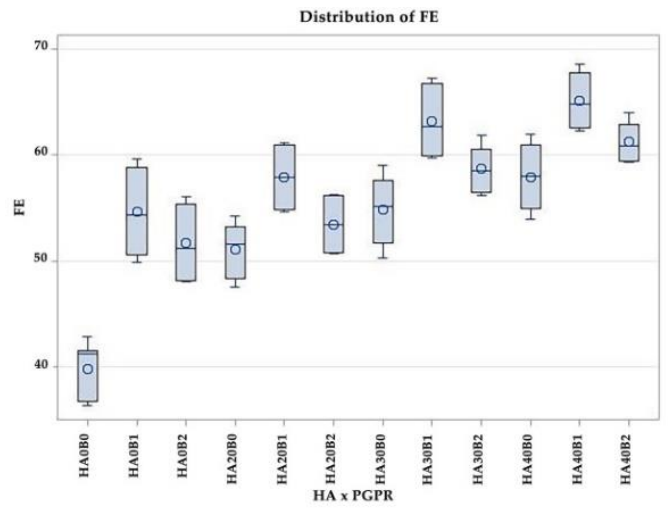

(e)

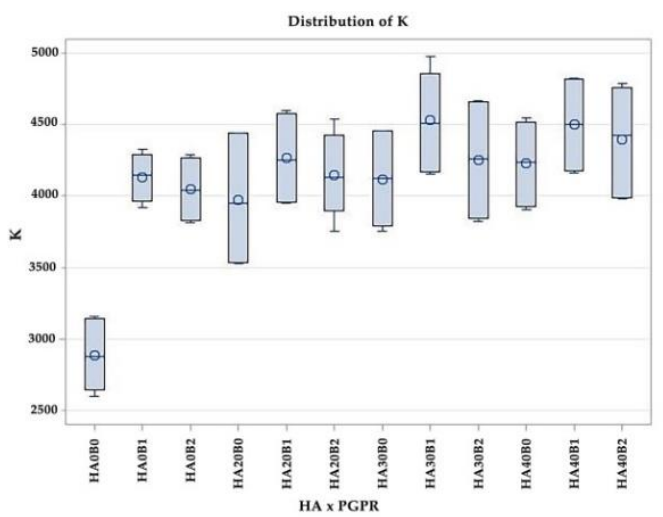

(b)

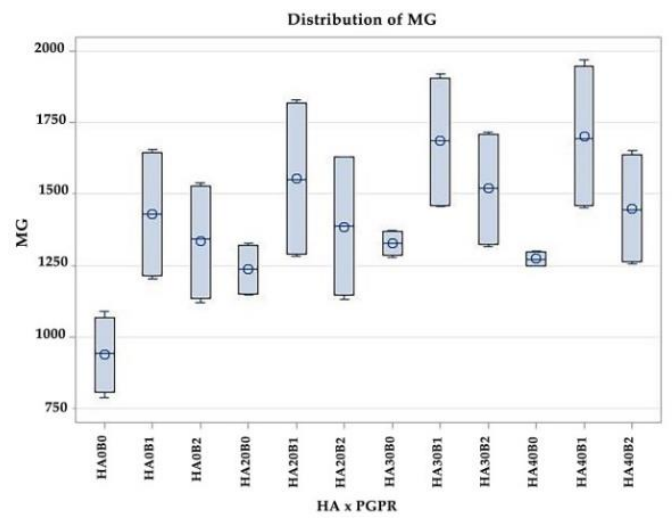

(d)

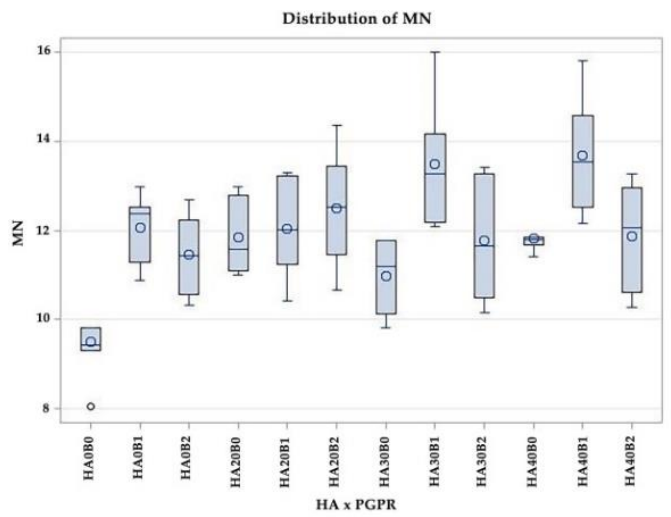

(f)

Figure 4. Phosphorus content $\left(m g \mathrm{~kg}^{-1}\right)(\boldsymbol{a})$, potassium content $\left(\mathrm{mg} \mathrm{k} \mathrm{g}^{-1}\right)(\boldsymbol{b})$, calcium content $\left(m g \mathrm{~kg}^{-1}\right)(\boldsymbol{c})$, magnesium content $\left(\mathrm{mg} \mathrm{kg^{-1 }}\right)(\boldsymbol{d})$, iron content $\left(\mathrm{mg} \mathrm{kg^{-1 }}\right)(\boldsymbol{e})$ and manganese content $\left(\mathrm{mg} \mathrm{kg}^{-1}\right)(\boldsymbol{f})$ of safflower seeds affected by bacterial inoculation and humic acid. $B_{0}$ : without bacteria; $B_{1}$ : B. subtilis OSU-142; $B_{1}+20, B_{1}+30$, and $B_{1}+40:$ B. subtilis OSU-142 with 200, 300 and $400 \mathrm{~kg} \mathrm{ha}{ }^{-1}$ of HA, respectively; $B_{2}: B$. megatorium M3; $B_{2}+20, B_{2}+30$ and $B_{2}+40:$ B. megatorium M3 with 200, 300 and $400 \mathrm{~kg} \mathrm{ha}^{-1}$ of HA, respectively

\section{Discussion}

In the present study, the plant growth-promoting rhizobacteria (Bacillus megatorium and Bacillus subtilis) and humic acids isolated from leonardite, individually or in combinations, was applied on safflower plants grown in the field trials under semi-arid conditions. Both plant growth promoting rhizobacteria inoculation and humic acid doses 
significantly increased the growth parameters, seed yield and mineral concentrations in seeds (except for $\mathrm{Cu}$ ) in comparison with control plants (grown in without PGPR and HA application), and further improved when applied in combination with humic acids. Inoculation of $\mathrm{N}_{2}$-fixing Bacillus subtilis strain OSU-142 effectively improved plant growth when compared to P-solubilizing Bacillus megatorium strain M3 and control, and increased plant height by $21.8 \%$, stem diameter by $11.8 \%$, numbers of branch and capitula per plant by 22.1 and $34.5 \%$, respectively, number of seeds per capitilum by 17.1, seed and oil yields by 47.1 and $61.5 \%$, when compared to the untreated control plants. Inoculation of Bacillus megatorium M3 produced the highest $\mathrm{P}$ concentration in seed, while the highest $\mathrm{K}, \mathrm{Ca}, \mathrm{Mg}, \mathrm{Fe}$ and $\mathrm{Mn}$ concentrations were recorded with Bacillus subtilis OSU-142 bacterial inoculation $(56.1 \%, 62.9 \%, 81.1 \%, 63.8 \%$ and $44.0 \%$ increases in $\mathrm{K}, \mathrm{Ca}, \mathrm{Mg}, \mathrm{Fe}$ and $\mathrm{Mn}$ when compared to control, respectively). The inoculation with PGPR strains in all of humic acid doses significantly increased $\mathrm{Zn}$ accumulation in seed about $68.3 \%$ - $76.4 \%$, compared to untreated safflower plants. Nitrogen and water requirements are the major limiting factors in safflower plant growth and productivity (Dajue and Mündel, 2006). Cakmakci et al. (2001) reported that inoculation of $\mathrm{N}_{2}$-fixing Bacillus subtilis OSU-142 may satisfy nitrogen requirements of sugar beet and barley under field conditions in highland areas, and this bacteria inoculant significantly improved seed yields. Another field studies indicated that Bacillus megatorium might have phosphorus dissolving ability since it gave similar increases in growth and yield consistently to alone P application (Cakmakci et al., 2006; Orhan et al., 2006; Elkoca et al., 2010). Furthermore, the various studies with Bacillus subtilis and Bacillus megatorium reported remarkable growth and yield increases in potato (Ekin, 2019), common bean (Elkoca et al., 2010), sour cherry (Karakurt et al., 2011), raspberry (Orhan et al., 2006), apricot (Esitken et al., 2003) and some turfgrass species (Acikgoz et al., 2016). However, no data were reported on growth promotion with inoculation of this Bacillus genus in safflower plants. The literature on plant growth promoting rhizobacteria regarding safflower included mostly Pseudomonas, Azosprillum and Azotobacter spp. inoculation which were used to improve nitrogen uptake (Mirzakhani et al., 2009; Soleymanifard and Sidat, 2011; Sharifi et al., 2017; Nosheen et al., 2018), root morphology (Nosheen et al., 2011) and protein quantity and quality of safflower seeds (Nosheen et al., 2016). These researchers mainly observed marked changes in primary safflower metabolism in response to plant growth-promoting bacterial species; there were also strong effects of PGPR applied in improving root morphology and plant growth, and increasing endogenous hormonal levels (indole-3-acetic acid and gibberellic acid) in safflower leaves.

In the present study, humic acid treatment increased growth parameters and yields above values in controls (Tables 2 and 3). The increasing the humic acid dose from $200 \mathrm{~kg} \mathrm{ha}^{-1}$ to $400 \mathrm{~kg} \mathrm{ha}^{-1}$ generally was accompanied by a linear increase in growth parameters (except capitilum diameter and sterile seed percentage). Humic acid doses affected not significantly capitilum diameter only, while $200 \mathrm{~kg} \mathrm{ha}^{-1}$ humic acid dose significantly decreased the sterile seed percentage compared to the control (Tables 2 and 3). However, the highest seed yields recorded with the application of 300 and 400 $\mathrm{kg} \mathrm{ha}^{-1}$ humic acid doses which was statistically similar (Table 3). In different studies, safflower crops showed consistent increases with humic acid treatments at the different locations (Basalma, 2014; Mehraban and Miri, 2017). Enhanced plant growth and seed yield were also suggested to explain the beneficial effects of humic acid. Hajghani et al. (2016) similarly promoted the safflower growth and development as well as seed and oil 
yields by humic substance application. Previous reports had shown that the beneficial effect of humic substances on plant growth may be related to increased fertilizer and water use efficiency, reducing soil compaction, enhancing total root area (especially lateral root emergence and root hairs) and plant biomass (Canellas and Olivares, 2014) and increasing soil microflora (Puglisi et al., 2013). In various field experiments, direct effects of humic acids on plant growth were well described in cultivation of various crops, such as potato (Suh et al., 2014), tomato (Olivares et al., 2015), maize (Canellas et al., 2013) and Hungarian vetch (Esringu et al., 2016). However, Canellas and Olivares (2014) recently reviewed the effects on plant metabolism of humic substance alone and in combination with plant growth promoting rhizobacteria, and theirs agronomical relevance.

Humic acid and plant growth promoting rhizobacteria application significantly affected plant growth development and production of safflower seed; however, their co-application further increased these agronomical parameters. Inoculation with Bacillus subtilis OSU-142 triggered ameliorative effects in terms of seed and oil yields at both 300 and $400 \mathrm{~kg} \mathrm{ha}^{-1}$ humic acid doses; these effects enhanced seed and oil production by average $162 \%$ and $221 \%$, respectively, relative the control plants in semiarid conditions (Table 3, Fig. 3). Previous reports had shown that integrated effects of plant growth promoting rhizobacteria and humic acid further increased plant growth, seed yield and quality in safflower (Mirzakhani et al., 2009; Sharifi et al., 2017), probably because of synergisms between improved nutritional status and plant stimulation factors; the net effects increased branch numbers, capitilum and stem diameters, 1000 seed weight, seed oil percentage, seed and oil yields and mineral compositions of seeds (Figs. 2, 3 and 4). Furthermore, humic substances are the most complex and biologically active organic matter compounds in the soil and stimulates both plants and microbial activities including plant growth promoting rhizobacteria through a number of mechanisms (e.g. through humic extracts of leonardite, compost or other organic fertilizer) (Nardi et al., 2009; Puglisi et al., 2013; Canellas and Olivares, 2014). PGPR enhancement of soil is largely attributable to biological $\mathrm{N}_{2}$ fixation, phosphorus solubilization and increases in the availability of nutrients in the rhizosphere. Availability of nutrients increases in response to root surface area enhancement, which is one of several architectural and biochemical changes in the root system induced by humic substance (Nardi et al., 2009; Canellas and Olivares, 2014). Inoculation of humic acids with plant growth promoting rhizobacteria may be used for both plant growth stimulation (Dobbss et al., 2010; Busato et al., 2012; Schoebitz et al., 2016; Silva et al., 2017; Shah and Wu, 2019) and plant disease protection (Cakmakci et al., 2001). The studies with co-application of humates and different PGPR strains previously reported remarkable growth and yield increases in safflower (Sharifi et al., 2017; Nosheen et al., 2018).

\section{Conclusions}

Recently, interest in safflower production has been renewed as a result of drought tolerance and the suitability of its oil for nutritional, industrial or biofuel purposes. This study shows that safflower variety Dincer adapted well to semi-arid conditions of Turkey and is a viable alternative to other oilseed crops. In the study, alone application of safflower seeds with both humic acid and plant growth-promoting rhizobacteria (Bacillus megatorium and Bacillus subtilis) produced highly increases in terms of seed 
and oil yields of safflower in semi-arid area. However combined application of plant growth promoting rhizobacteria and humic acid significantly improved growth and yield more than alone application of each partner under rainfed field condition. This increase was also supported by the enhancement of nutrient contents in the safflower seeds. Finally, the Bacillus inoculants should be assessed for their potential to increase crop yields and food production under real field environment and this integrated approach could be become an effective method for safflower production under semiarid conditions in sustainable agriculture systems.

Acknowledgements. The author appreciates the valuable contributions by Dr. M. Figen Dönmez (kindly provided the PGPR), Prof. Dr. Ismail Hakki Ekin (Department of Microbiology), Faruk Oguz (technical support) and Prof. Dr. Abdullah Yesilova (statistical analyses).

\section{REFERENCES}

[1] Acikgoz, E., Bilgili, U., Sahin, F., Guillard, K. (2016): Effect of plant growth-promoting Bacillus sp. on color and clipping yield of three turfgrass species. - J. of Plant Nutr 39(10): 1404-1411. https://doi.org/10.1080/01904167.2016.1143501.

[2] Ahmad, S., Daur, I., Al-Solaimani, S. G., Mahmood, S. (2016): Plant growth promoting rhizobacteria and humic acid improve growth and yield of organically grown canola. Int. J. of Engineering Research \& Techn 5(5): 424-428.

[3] Basalma, D. (2014): Effects of humic acid on the emergence and seedling growth of safflower (Carthamus tinctorius L.). - Turkish J. of Agricultural and Natural Sci. Special Issue 2: 1402-1406. https://dergipark.org.tr/download/article-file/142280.

[4] Busato, J. G., Silva, L. L., Aguiar, N. O., Canellas, L. P., Olivares, F. L. (2012): Changes inlabile phosphorus forms during maturation of vermicompost enriched with phosphorussolubilizing and diazotrophic bacteria. - Bioresour. Technol. 110: 390-395. https://doi.org/10.1016/j.biortech.2012.01.126.

[5] Cakmakci, R., Kantar, F., Sahin, F. (2001): Effect of N2-fixing bacterial inoculations on yield of sugar beet and barley. - J. Plant Nutr. Soil Sci. 164: 527-531. https://doi.org/10.1002/1522624(200110)164:5<527::AID-JPLN527>3.0.CO;2-1.

[6] Cakmakci, R., Donmez, F., Aydın, A., Sahin, F. (2006): Growth promotion of plants by plant growth promoting rhizobacteria under greenhouse and two different field soil conditions. - Soil Biol. and Biochem. 38: 1482-1487. https://doi.org/10.1016/j.soilbio.2005.09.019.

[7] Calvo, P., Nelson, L., Kloepper, J. W. (2014): Agricultural uses of plant biostimulants. Plant Soil 383: 3-41. https://doi.org/10.1007/s11104-014-2131-8.

[8] Canellas, L. P., Balmori, D. M., Médici, L. O., Aguiar, N. O., Campostrini, E., Rosa, R. C. C., Façanha, A. R., Olivares, F. L. (2013): A combination of humic substances and Herbaspirillum seropedicae inoculation enhances the growth of maize (Zea mays L.). Plant Soil 366: 119-132.

[9] Canellas, L. P., Olivares, F. L. (2014): Physiological responses to humic substances as plant growth promoter. - Chem Biol Technol Agric 4: 1-3. https://doi.org/10.1186/2196-5641-1-3 https://doi.org/10.1007/s11104-012-1382-5.

[10] Cassán, F., Perrig, D., Sgroy, V., Masciarelli, O., Penna, C., Luna, V. (2009): Azospirillum brasilense Az39 and Bradyrhizobium japonicum E109, inoculated singly or in combination, promote seed germination and early seedling growth in corn (Zea mays L.) and soybean (Glycine max L.). - Eur J Soil Biol 45: 28-35. https://doi.org/10.1016/j.ejsobi.2008.08.005. 
[11] Chavoushi, M., Najafi, F., Salimi, A., Angaji, S. A. (2019): Improvement in drought stress tolerance of safflower during vegetative growth by exogenous application of salicylic acid and sodium nitroprusside. - Ind. Crops Prod. 134: 168-176.

https://doi.org/10.22059/ijhst.2019.277800.283.

[12] Dajue, L., Mündel, H. H. (2006): Safflower. Carthamus tinctorius L. Promoting the conservation and use of under-utilized and neglected crops. - 7. Institute of Plant Genetics and Crop Plant Research, Gatersleben/International Plant Genetic Resources Institute, Rome, Italy, pp. 83.

[13] Dobbss, L. B., Canellas, L. P., Olivares, F. L., Aguiar, N. O., Peres, L. E. P., Azevedo, M., Spaccini, R., Piccolo, A., Facanha, A. R. (2010): Bioactivity of chemically transformed humic matter from vermicompost on plant root growth. - J. Agric. Food Chem. 58: 3681-3688. https://doi.org/10.1021/jf904385c.

[14] Ekin, Z. (2005): Resurgence of safflower (Carthamus tinctorius L.) utilization: A global view. - Journal of Agronomy 4(2): 83-87. https://doi.org/10.3923/ja.2005.83.87.

[15] Ekin, Z. (2019): Integrated use of humic acid and plant growth promoting rhizobacteria to ensure higher potato productivity in sustainable agriculture. - Sustainability 11: 3417. https://doi.org/10.3390/su11123417.

[16] El-Howeity, M. A., Asfour, M. M. (2012): Response of some varieties of canola plant (Brassica napus L.) cultivated in a newly reclaimed desert to plant growth promoting rhizobacteria and mineral nitrogen fertilizer. - Annals of Agricultural Sciences 57(2): 129-136. https://doi.org/10.1016/j.aoas.2012.08.006.

[17] Elkoca, E., Turan, M., Donmez, M. F. (2010): Effects of single, dual and triple 1noculations with Bacillus subtlls, Bactllus megaterium and Rhizobium leguminosarum $B v$. Phaseoli on nodulation, nutrient uptake, yield and yield parameters of common bean (Phaseolus vulgaris L. Cv. 'Elkoca-05'). - Journal of Plant Nutrition 33(14): 2104-2119. https://doi.org/10.1080/01904167.2010.519084.

[18] Esitken, A., Karlidag, H., Ercisli, S., Turan, M., Sahin, F. (2003): The effect of spraying a growth promoting bacterium on the yield, growth and nutrient element composition of leaves of apricot (Prunus armeniaca L. cv. Hacihaliloglu). - Australian J. of Agric. Res. 54: 377-380. https://doi.org/10.1071/AR02098.

[19] Esringu, A., Kaynar, D., Turan, M., Ercisli, S. (2016): Ameliorative effect of humic acid and plant growth-promoting rhizobacteria (PGPR) on Hungarian vetch plants under salinity stress. - Commun Soil Sci Plant Anal 47: 602-18. https://doi.org/10.1080/00103624.2016.1141922.

[20] Glick, B. R. (2012): Plant Growth-Promoting Bacteria: Mechanisms and Applications. Hindawi Publishing Corporation, Scientifica: Waterloo, Canada.

[21] Hajghani, M., Ghalavand, A., Modarres-Sanavy, S. A. M., Asadipour, A. (2016): The response of safflower seed quality characteristics to organic and chemical fertilization. Biological Agric. \& Hort. 32(2): 139-147. https://doi.org/10.1080/01448765.2015.1094674.

[22] Hoyos-Carvajal, L., Orduz, S., Bissett, J. (2009): Growth stimulation in bean (Phaseolus vulgaris L.) by Trichoderma. - Biol Control 51: 409-416. https://doi.org/10.1016/j.biocontrol.2009.07.018.

[23] Hungria, M., Campo, R. J., Souza, E. M., Pedrosa, F. O. (2010): Inoculation with selected strains of Azospirillum brasilense and A. lipoferum improves yields of maize and wheat in Brazil. - Plant Soil 331: 413-425. https://doi.org/10.1007/s11104-009-0262-0.

[24] Karakurt, H., Kotan, R., Dadasoglu, F., Aslantas, R., Sahin, F. (2011): Effects of plant growth promoting rhizobacteria on fruit set, pomological and chemical characteristics, color values, and vegetative growth of sour cherry (Prunus cerasus cv. Kütahya). - Turk J Biol 35: 283-291. https://doi.org/10.3906/biy-0908-35.

[25] Lucas, J. A., Ramos Solano, B., Montes, F., Ojeda, J., Megias, M., Gutierrez Mañero, F. J. (2009): Use of two PGPR strains in the integrated management of blast disease in rice (Oryza sativa L.) in Southern Spain. - Field Crops Res 114: 404-410. 
https://doi.org/10.1016/j.fcr.2009.09.013.

[26] Mehraban, A., Miri, M. (2017): Influence of humic acid and mycorrhiza on some characteristics of safflower (Carthamus tinctorius). - Journal of Research in Ecology 5(1): 508-514. http://jresearchbiology.com/documents/EC0275.pdf.

[27] Mirzakhani, M., Ardakanı, M. R., Aeene Band, A., Rejalı, F., Shıranı Rad, A. H. (2009): Response of spring safflower to co-inoculation with Azotobacter chroococum and Glomus intraradices under different levels of nitrogen and phosphourus. - American J. of Agric. and Biol. Sci. 4: 255-261. https://doi.org/10.3844/ajabssp.2009.255.261.

[28] Nardi, S., Carletti, P., Pizzeghello, D., Muscolo, A. (2009): Biological activities of humic substances. - In: Seni, N., Xing, B., Huang, P. M. (eds.) Biophysico-chemical Processes Involving Natural Nonliving Organic Matter in Environmental Systems. Wiley, New Jersey, pp. 305-340.

[29] Nosheen, A., Bano, A., Ullah, F., Farooq, U., Yasmin, Y., Hussain, I. (2011): Effect of plant growth promoting rhizobacteria on root morphology of safflower (Carthamus tinctorius L.). - African J. of Biotech. 10(59): 12639-12649. https://doi.org/10.5897/AJB11.1647.

[30] Nosheen, A., Bano, A., Yasmin, H., Keyani, R., Habib, R., Shah, S. T. A., Naz, R. (2016): Protein quantity and quality of safflower seed improved by NP fertilizer and Rhizobacteria (Azospirillum and Azotobacter spp.). - Front. Plant Sci. 7: 104. https://doi.org/10.3389/fpls.2016.00104.

[31] Nosheen, A., Naz, R., Tahir, A. T., Yasmin, H., Keyani, R., Mitrevski, B., Bano, A., Chin, S. T., Marriott, P. J. (2018): Improvement of safflower oil quality for biodiesel production by integrated application of PGPR under reduced amount of NP fertilizers. PLoS ONE 13: 8. https://doi.org/10.1371/journal.

[32] Olivares, F. L., Aguiar, N. O., Rosa, R. C. C., Canellas, L. P. (2015): Substrate biofortification in combination with foliar sprays of plant growth promoting bacteria and humic substances boosts production of organic tomatoes. - Sci. Hortic. 183: 100-108. https://doi.org/10.1016/j.scienta.2014.11.012.

[33] Orhan, E., Esitken, A., Ercisli, S., Turan, M., Fikrettin, S. (2006): Effects of plant growth promoting rhizobacteria (PGPR) on yield, growth and nutrient contents in organically growing raspberry. - Sci. Hort. 111: 38-43. https://doi.org/10.1016/j.scienta.2006.09.002.

[34] Puglisi, E., Pascazio, S., Suciu, N., Cattani, I., Fait, G., Spaccini, R., Crecchio, C., Piccolo, A., Trevisan, M. (2013): Rhizosphere microbial diversity as influenced by humic substance amendments and chemical composition of rhizodeposits. - J. Geochem. Explor. 129: 82-94.

[35] Rana, A., Joshi, M., Prasanna, R., Shivay, Y. S., Nain, L. (2012): Biofortification of wheat through inoculation of plant growth promoting rhizobacteria and cyanobacteria. European J Soil Biol 50: 118-26. https://doi.org/10.1016/j.ejsobi.2012.01.005.

[36] Rosas, S. B., Avanzin, G., Carlier, E., Pasluosta, C., Pastor, N., Rovera, M. (2009): Root colonization and growth promotion of wheat and maize by Pseudomonas aurantiaca SR1. - Soil Biol Biochem 41: 1802-1806. https://doi.org/10.1016/j.soilbio.2008.10.009.

[37] Ryan, J., Estefan, G., Rashid, A. (2012): Soil and Plant Analysis Laboratory Manual. Sentific Publishers, 2nd Edition. ISBN-10: 8172337655, ISBN-13: 978-8172337650.

[38] Schoebitz, M., López, M. D., Serrí, H., Martínez, O., Zagal, E. (2016): Combined application of microbial consortium and humic substances to improve the growth performance of blueberry seedlings. - J Soil Sci Plant Nutr. 16: 1010-1023. http://dx.doi.org/10.4067/S0718-95162016005000074.

[39] Shah, F., Wu, W. (2019): Soil and crop management strategies to ensure higher crop productivity within sustainable environments. - Sustainability 11(5): 1485-1504. https://doi.org/10.3390/su11051485.

[40] Shahid, M., Hameed, S., Imran, A., Ali, S., Elsas, J. D. (2012): Root colonization and growth promotion of sunflower (Helianthus annuus L.) by phosphate solubilizing 


$$
-1900-
$$

Enterobacter sp. Fs-11. - World J Microbiol Biotechnol 28: 2749-2758. https://doi.org/10.1007/s11274-012-1086-2.

[41] Sharifi, R. S., Namvar, A., Sharifi, R. S. (2017): Grain filling and fatty acid composition of safflower fertilized with integrated nitrogen fertilizer and biofertilizers. - Pesq. agropec. bras. Brasília 52(4): 236-243. http://dx.doi.org/10.1590/s0100$204 \times 2017000400003$.

[42] Silva, S. F., Olivares, F. L., Canellas, L. P. (2017): The biostimulant manufactured using diazotrophic endophytic bacteria and humates is effective to increase sugarcane yield. Chem Biol Technol Agric 4: 24. https://doi.org/10.1186/s40538-017-0106-8.

[43] Soleymanifard, A., Sidat, S. A. (2011): Effect of inoculation with bio-fertilizer in different nitrogen levels on yield and yields components of safflower under dry land conditions. - American Eurasian J. of Agric. and Envir. Sci. 11: 473-477. https://www.idosi.org/aejaes/jaes11(4)11/3.pdf.

[44] Suh, H. Y., Yoo, K. S., Suh, S. G. (2014): Tuber growth and quality of potato (Solanum tuberosum L.) as affected by foliar or soil application of fulvic and humic acids. - Hortic. Environ. Biotechnol. 55(3): 183-189. https://doi.org/10.1007/s13580-014-0005-x.

[45] Thonar, C., Lekfeldt, J. D. S., Cozzolino, V., Kundel, D., Kulhánek, M., Mosimann, C., Neumann, G., Piccolo, A., Symanczik, S., Walder, F. (2017): Potential of three microbial bio-effectors to promote maize growth and nutrient acquisition from alternative phosphorous fertilizers in contrasting soils. - Chem Biol Technol Agric. 4: 7. https://doi.org/10.1186/s40538-017-0088-6. 